\title{
Statistical and Geostatistical Analysis of Lineaments Network Mapped in The Precambrian Basement: Case of Divo-Oume Region (Southern Cote d'Ivoire)
}

\author{
Bertrand Ouesse Tagnon \\ Geosciences Research Unit/ \\ Pole of Research in Environment and Sustainable Development / \\ Nangui Abrogoua University, Abidjan, Côte d'Ivoire \\ Prof. Theophile Lasm \\ Department of Water Science, Technology and Environment Engineering/ \\ Felix Houphouet-Boigny University, Abidjan, Cote d'Ivoire /

\section{Doctor Aristide G. Douagui \\ Prof. Issiaka Savane \\ Geosciences Research Unit/} \\ Pole of Research in Environment and Sustainable Development / \\ Nangui Abrogoua University, Abidjan, Côte d'Ivoire
}

doi: 10.19044/esj.2016.v12n33p299 URL:http://dx.doi.org/10.19044/esj.2016.v12n33p299

\begin{abstract}
The high populated and dense agricultural region of Divo-Oumé, in the southern part of Côte d'Ivoire, periodically faces drinking water scarcity and lack of reliable water resources management tools. This study presents a statistical and geostatistical analysis of lineaments network, conducted in Divo-Oumé region, in order to contribute to a better understanding of local Precambrian basement aquifer. Fractures network has been characterized through the analysis of the attributes of lineaments derived from conjoint Radarsat and Asar images. The average length of lineaments is $2.15 \mathrm{~km}$ and around this value, high dispersion is observed $(\mathrm{CV}=133 \%)$. A total of 3,559 cross-points (CP) are identified and most of spacing values (84.3\%) are less than $2 \mathrm{~km}$. The statistical distribution of lineaments lengths, cross-points and spacing follow power law, highlighting the fractal nature of fractures network. Also, the variation coefficient $(\mathrm{CV}=51 \%)$ of lineaments spacing and the characteristic exponent of power law in the case of lineament lengths $(\alpha=2.55)$ would indicate respectively, fracturing process is intense in the region and fracture network reach a mature stage of development. The geostatistical analysis showed that the variograms of lineaments cumulative lengths (CL) and cross-points (CP) are structured. These variograms have the
\end{abstract}


same behavior, reflecting the intrinsic character of CL and CP. However, the correlation ranges of CL are higher than those of CP.

These results could be useful for understanding groundwater flow and the establishment of water resource management tools.

Keywords: Statistical analysis, geostatistical, lineaments network, DivoOumé region, Côte d’Ivoire

\section{Introduction}

Optimum exploitation and rational management of aquifers in basement regions requires good knowledge of both geometry and hydraulic properties of the fractures that affected the rock mass. The conceptual model of bedrock aquifers consists of a top weathered layer and a bottom fractured layer that concentrates most of the groundwater (Biemi, 1992; Savane, 1997; Wyns et al., 2004 and Lachassagne et al., 2011). Fractures give to rocks, most of their hydrodynamic properties. Hydraulic tests are commonly used to define the hydraulic properties of fractured aquifers, but those tests generally do not give information on the geometry of fractures (Lemieux et al., 2009). One the contrary, statistical and geostatistical approaches are most often used for the analysis of fractures attributes extracted from various methods (field observations, geophysical and remote sensing). These approaches are quite realistic for the characterization of geometric attributes of fractures, which are lengths, spacings, directions, intersections, openings and dips. The important role of these attributes, in the organization of the fracture network and its conductivity properties were observed by many authors such us Razack (1984); La Point and Hudson, (1985); Long and Billaux (1987); Cacas et al., (1990); Chilès and Marsily (1993); De Dreuzy et al., (2000); Chilès et al., (2000); Lasm (2000); Lasm and Razack (2001), Castaing et al., (2002). Darcel et al. (2003); Chilès (2004), Youan Ta et al., (2008) and Lemieux et al., (2009) who had used statistical and/or geostatistical approaches for modeling bedrock environment and assessment of fractures implication in subsurface flows. Statistical methods facilitate fracture attributes description (La Pointe and Hudson, 1985; Lasm, 2000), while geostatistical approaches, through the study of variogram structures, give information on the spatial deployment of fractures.

In the Divo-Oumé region, pressure on environment in general and on water resources in particular, is growing due to significant agricultural activities and mining expansion. Kouadio (2011) focusing on the impact of human activities on surface water, has revealed an increased degradation of vegetation cover, followed by an increased runoff and a decreased infiltration. The conditions of access to drinking water have continuously deteriorated in this densely populated and rapidly growing region where $80 \%$ 
of the population rely on groundwater to meet their needs. The drinking water supply initiatives by boreholes repeatedly failed during recent years. Indeed, the "Programme Présidentiel d’Urgence” (PPU) 2 and 3 (2013 and 2015), realized $48 \%$ of unsuccessful drillings in the only department of Divo, according to the "Direction Territoriale de l'Hydraulique” (DTH). However, only two studies (Soro, 2002 and Baka, 2012) focus on groundwater and hydrogeological environment have been carried out in this region.

The present study deals with the apprehension of the fracture network in the Precambrian basement region of Divo-Oumé, through statistical and geostatistical analysis of lineaments' attributes. This study is a continuation of the work conducted in various areas of Côte d'Ivoire (Lasm, 2000, Youan Ta, 2008; Youan Ta et al., 2008; Baka, 2012; Koudou,et al. 2013; Koudou, et al., 2014. However, the treatment of lineaments derived from the combination of Radarsat-1 and Asar images, and statistical/geostatistical analysis of lineaments cross-points (CP), are the particularities of this study and could provide additional information to previous work carried out in Côte d'Ivoire.

All information obtained will be a contribution to the establishment of regional water resources management tools.

\section{Geography and geology of the study area}

The Divo-Oumé region is located in southern part of Côte d'Ivoire, between longitudes $5^{\circ}$ and $6^{\circ}$ West and latitudes $5^{\circ}$ and $6^{\circ} 40^{\prime}$ North (Figure 1). This area of $12.500 \mathrm{~km}^{2}$, has a dense and rapidly growing (over $3.8 \%$ ) population, due to important economic activities (agriculture and mining). The river system is also dense and the main ones, which are Niouniourou, Boubo and Gô, are costal. Bandama River forms the eastern boundary of Oumé department (North of the study area) and Téné, its tributary, runs through the northern part of the study area. The region is dominated by a vast pediplain and valleys. However, some inselbergs and massifs of basic rocks, are observed.

In geological terms, the Divo-Oumé region belongs to Precambrian granitic and volcanosedimentary basement (Figure 1), established throughout complex orogenic phases. The granitic rocks set up during "Liberian" tectono-volcanic event (2750 to 2579 million years ago), and they were rejuvenated later by “Eburnean” (2090 to 1830 million year ago) one. The establishment of volcanosedimentary rocks was made thereafter. A marine basin was installed in the peneplain formed by the cratonic stage of “Liberian” megacycle (3000 - 2300 million years ago). Into this marine basin, deep normal faults opened up large subsidence furrows, inducing the rising of basic magma. During its ascent, this magma is differentiated, contaminated and produced important lava, which is joined by various 
sediments such as microquartzites of chemical origin, to form the volcanosedimentary complex. The "Birimian" tectono-volcanic phase (2000-1880 mya), latest step of "Eburnean" orogeny, generated later, thick detrital accumulations deposited above volcanosedimentary rocks (Koita et al., 2013).

In its southern part, the study area is attached to a narrow band of the sedimentary basin, from Meso-Cenozoic and Quaternary (Geomine, 1982;

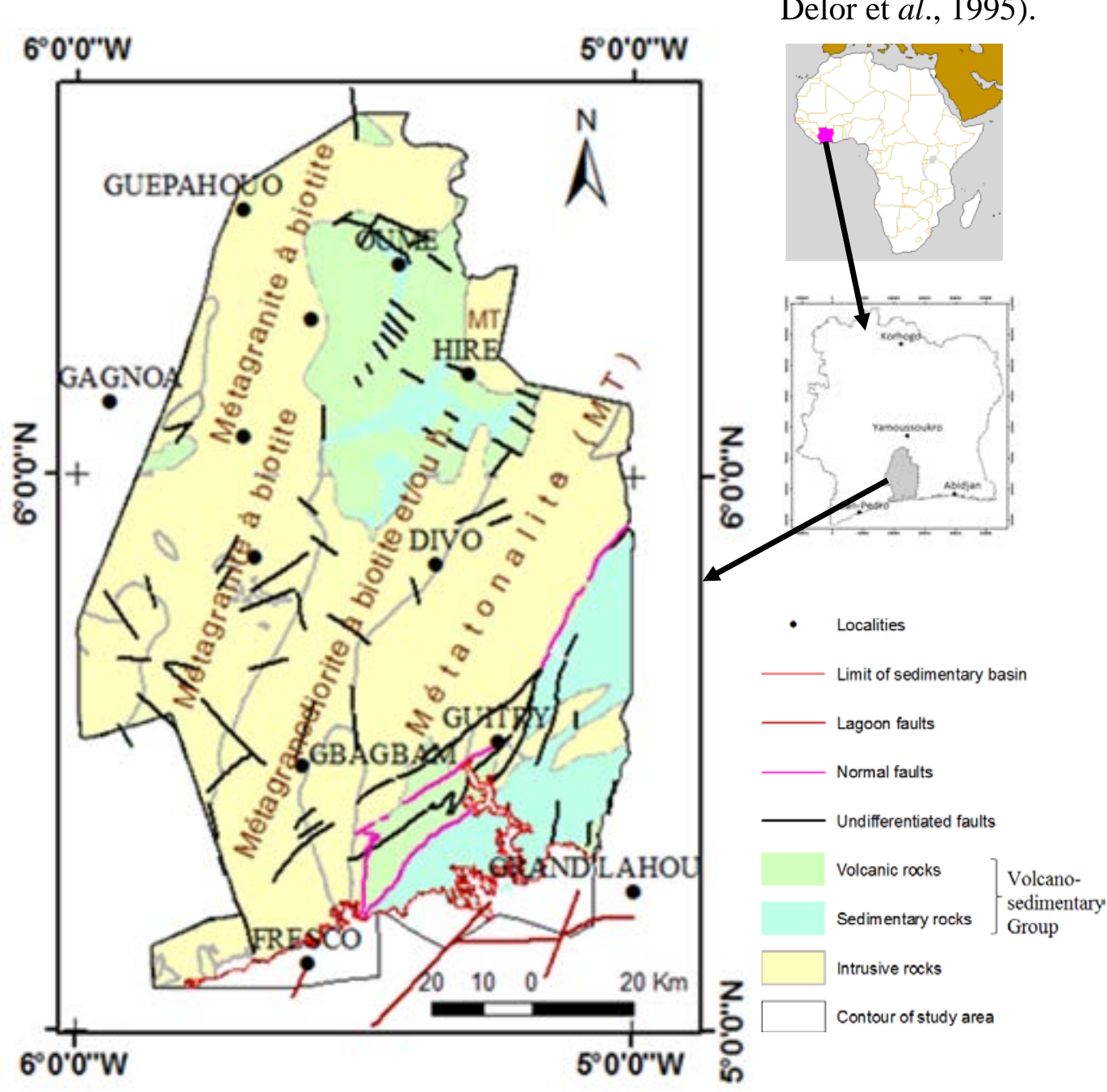

Figure 1: Location and simplified geological map of the region of Divo-Oumé (modified from Delor et al., 1995).

The outcrops of rocks in the study area (Figure 2), are limited because of deep weathered layer overhanging the substratum. They are fractured in certain places (Figure 2). 

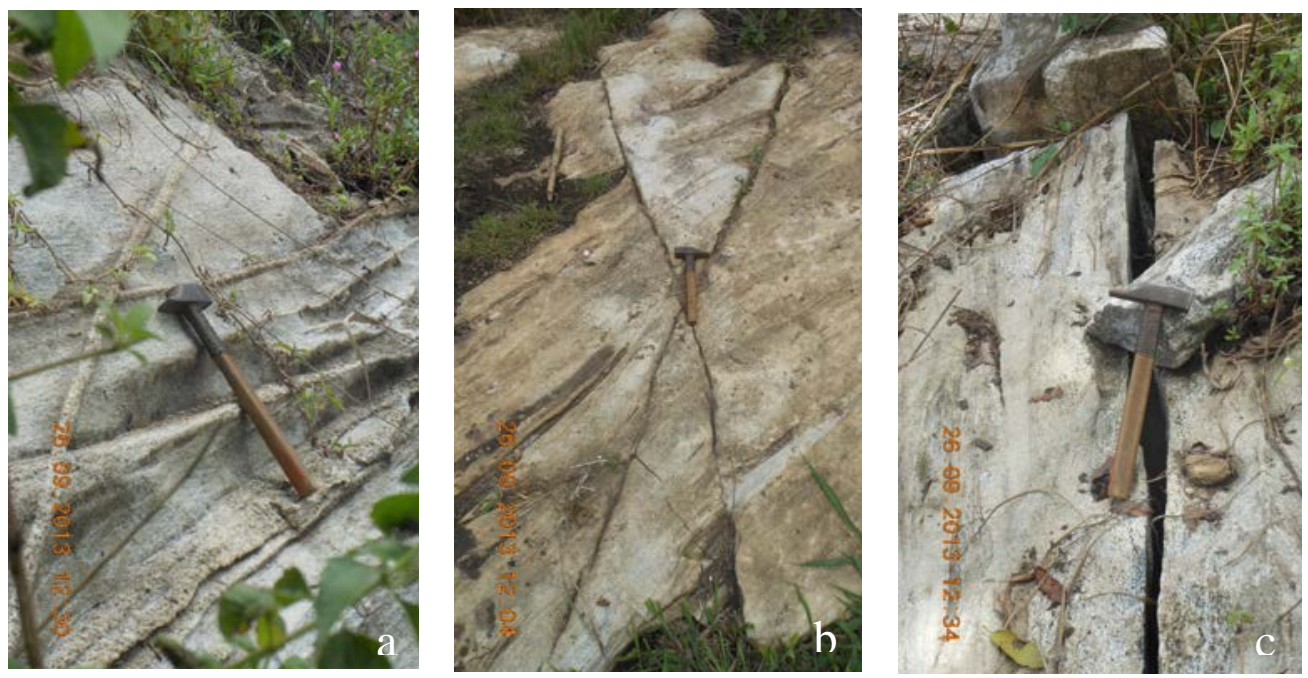

Figure 2: granitic outcrops at Bribory, near the town of Divo: a) quartz’s veins, b) cross fractures, c) open fracture.

\section{Material and methods \\ Material}

The lineament map (Figure 3) is the main data of the study. It was derived from conjoint Radarsat-1 and Asar / Envisat images, of which some characteristics are presented on table 1 . Radar waves seem to be most adapted to tropical humid areas because, contrary to optical ones, they are not affected by atmospheric diffusion. Also, through important sensitivity to surface characteristics such as roughness and humidity, radar data are particularly effective for the mapping of linear structures corresponding to faults, fractures and lithological contacts (Wade et al., 2001). 


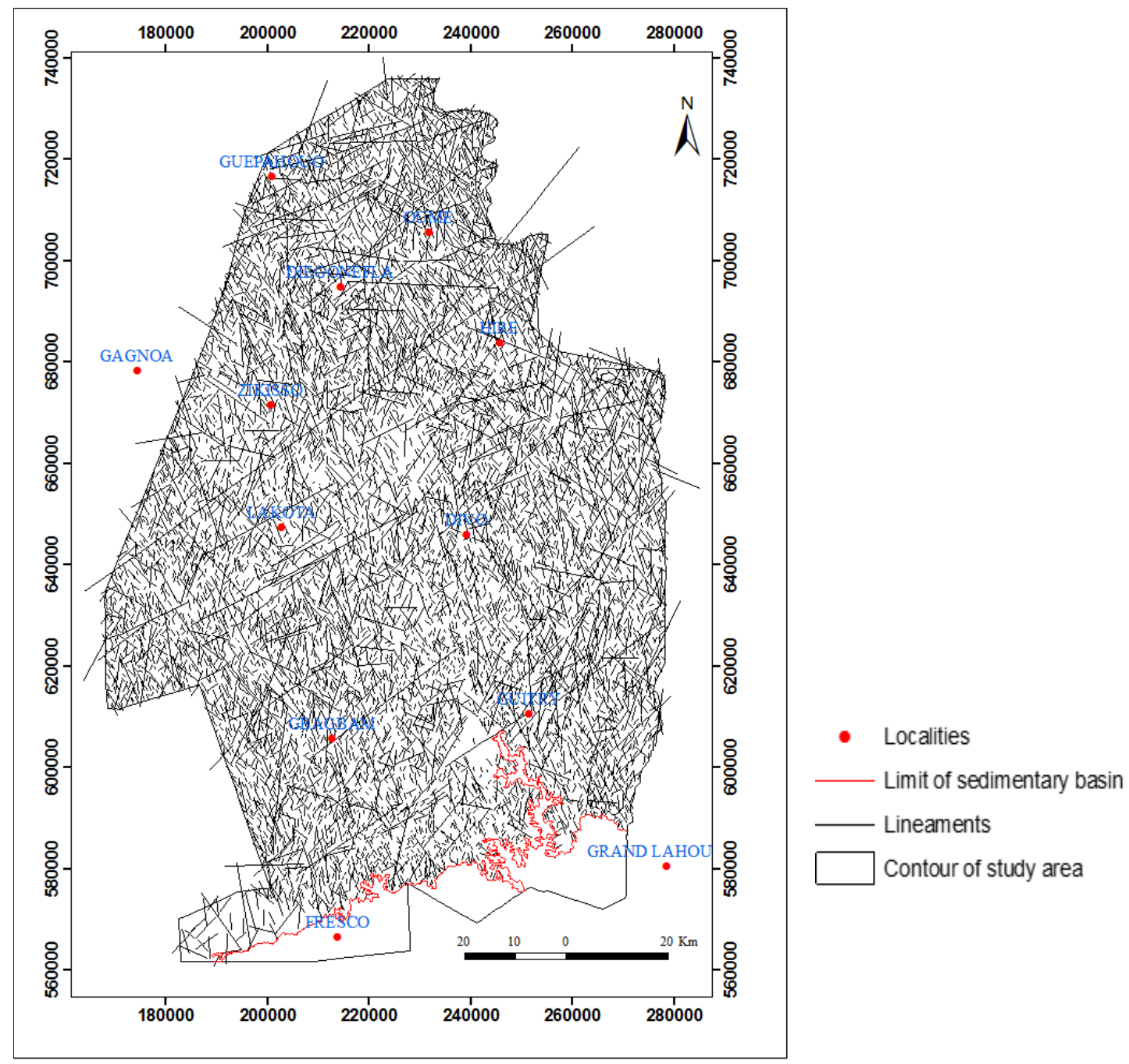

Figure 3: Map of lineaments of Divo-Oumé, extracted from Radarsat-1 and Asar images.

Jointly using of RADARSAT-1 and ASAR image aims to obtain additional information through the exploitation of their different spatial resolution (50 m for RADARSAT-1 and $30 \mathrm{~m}$ for ASAR) and polarization (HH for Radarsat-1 and VV for Asar). The image RADARSAT-1, with a coarser resolution tend to raise the larger size lineaments, while ASAR images are better to map relatively shorter ones. Also, various polarization combinations can provide complementary information on targets and improve the identification and discrimination between elements (CCT, 2007). 
Table 1: characteristics of radar images.

\begin{tabular}{ccccc}
\hline Sensors & Dates & Mode & Band & $\begin{array}{c}\text { Spatial } \\
\text { Resolution }\end{array}$ \\
\hline & $26 / 12 / 2006$ (scene 4) & & & \\
ASAR Level 1 & $16 / 03 / 2004$ (scene 5) & Image Mode & $\mathrm{C}(\lambda=5.6 \mathrm{~cm})$ & $30 \mathrm{~m}$ (pixel : \\
(Polarization & $25 / 01 / 2004$ (scene 7) & $\begin{array}{c}\text { Precision } \\
\text { (IMP) }\end{array}$ & & $12.5)$ \\
\hline VAD) & $25 / 01 / 2004$ (scene 8) & ScanSAR & $\mathrm{C}(\lambda=5.6 \mathrm{~cm})$ & $50 \mathrm{~m}$ \\
$\begin{array}{c}\text { RADSAT-1 } \\
\text { (Polarization }\end{array}$ & Jan. 2001 & Scan & & \\
HH) & & & & \\
\hline
\end{tabular}

Methods

\section{Lineaments analysis techniques}

The analysis focused on lineaments' lengths, spacing and crosspoints.

The length of each lineament was obtained after the treatment of the structural map in a GIS environment. Scripts designed by Kim et al. (2004) were used to calculate within circular mesh, total length and number of lineaments cross-points. A Radius value of $2 \mathrm{~km}$ was chosen because a good mesh refinement was gotten with it, on the study area. The spacing between lineaments were evaluated with the module RAFESP of the calculation code RAFRAC (Razack, 1984).

\section{Statistical analysis techniques}

\section{Adjusting of lineaments' attributes to theoretical laws}

The lineaments' attributes have been adjusted to theoretical models (exponential, lognormal, gamma) and power law. Under the theory of Chi2 compliance test, the model with the best fits is obtained when the calculated Chi2 is less than the theoretical Chi2. The tests were conducted with a $10 \%$ significance level.

The adjustment to the power law consists in representing with a loglog graph, the frequency distribution of the parameter studied. Only aligned points are concerned with the adjustment. The expression of the power law is given as follows:

$$
N(l i)=a \times l i^{\alpha}
$$

With $l i$, the centers of class of considered parameter;

$\mathrm{N}$ : class frequency;

a: proportionality coefficient;

$\alpha$ : characteristic exponent of the power law.

\section{Geostatistical treatment of lineament attributes}

The basic idea of geostatistic is that in the nature, two observations located near each other, should, on average, more resemble each other than 
two distant ones. The variogram is the tool of geostatistic that highlights, if it exists, the structuring of the phenomenon studied. The variogram of the continuous function $\mathrm{Z}$ is defined by the equation below:

$$
\gamma(h)=\frac{1}{2} \operatorname{Var}[Z(x+h)-Z(x)]
$$

Where, Var is the variance, $\mathrm{Z}(\mathrm{x})$ is the $\mathrm{Z}$ value measured at position $\mathrm{x}, \mathrm{Z}(\mathrm{x}+\mathrm{h})$ is the value of $\mathrm{Z}$ measured at a distant $\mathrm{h}$ from the position $\mathrm{x}$.

Values of cumulative lengths (CL) and numbers of cross-points (CP) of lineaments were concerned by the geostatistical analysis. The study was carried out within geoR package, run into R software environment.

\section{Results}

\section{Statistical analysis of lineaments attributes}

\section{Lengths, spacing and cross-points statistics}

The statistical parameters of lengths, cross-points and spacing of lineaments are summarized in Table 2.

Table 2: Statistical data of lineaments' lengths, cross-points and spacings.

\begin{tabular}{cccccc}
\hline & $\begin{array}{c}\text { Total } \\
\text { number }\end{array}$ & Minimum & Maximum & Average & $\begin{array}{c}\text { standard } \\
\text { deviation }\end{array}$ \\
\hline $\begin{array}{c}\text { lengths } \\
(\mathrm{km})\end{array}$ & 7886 & 0.12 & 123.49 & 2.15 & 2.86 \\
$\begin{array}{c}\text { Cross- } \\
\text { points }\end{array}$ & 3559 & 0 & 18 & 3.93 & 3.16 \\
$\begin{array}{c}\text { Spacings } \\
(\mathrm{m})\end{array}$ & 1127 & 0.61 & 15403.42 & 1275.41 & 1390.66 \\
$\begin{array}{c}\text { Spacings } \\
<2000 \mathrm{~m}\end{array}$ & 950 & 0.61 & 1979 & 858.26 & 492.37 \\
$(84,3 \%)$ & & & & & \\
\hline
\end{tabular}

The total number of lineaments mapped after images processing is 7 886. Their size are variable, ranging between 0.12 and $124 \mathrm{~km}$ with an average and a standard deviation equal to 2.15 and $2.86 \mathrm{~km}$, respectively. These lengths are spread over 3 orders of magnitude, highlighting the heterogeneity of the environment. The value of coefficient of variation (CV $=133 \%$ ) indicates a dispersion among lineament lengths data.

For 7,886 lineaments mapped, there are 3,559 cross-points (CP) in the study area. The number of $\mathrm{CP}$ shows an important junction of lineaments. On average, 4 intersections are observed per mesh. The maximum number of $\mathrm{CP}$ per cell is 18 and the minimum is 0 . Meshes without CP are few (13.40\%).

The number of spacing is 1,127 and their values vary between $0.61 \mathrm{~m}$ and $15403 \mathrm{~m}$, with an average of $1,275.41 \mathrm{~m}$ and a standard deviation of $1,390.66(\mathrm{CV}=109 \%)$. Like the case of the cumulative lengths, there is a dispersion of values of lineaments spacing. Note that most of the spacing 
values (84.3\%), are less than $2 \mathrm{~km}$. In this subsample, the average is $858 \mathrm{~m}$ and the standard deviation is $492 \mathrm{~m}$. This low value of standard deviation shows a homogenization spacing values lower than $2 \mathrm{~km}$.

\section{Distribution of lineament length, cross-point and spacing Distribution of cumulative length (CL)}

The lineament CL distribution, according to the power law, is shown in figure $4 \mathrm{a}$. Only the linear part of the curve $(1.28 \mathrm{~km} \leq \ell \leq 13.04 \mathrm{~km})$, is concerned with this adjustment. Its expression is:

$N(l)=5559,5 \times \ell^{-2,55}$.

This adjustment is perfect $\left(\mathrm{R}^{2}=0.99\right)$ for the CL values ranged between $1.28 \mathrm{~km}$ and $13.04 \mathrm{~km}$. The exponent characteristic of the power law ( $\alpha=2.55$ ) is between 2 and 3. The values of CL outside this range are affected by the resolution limit.

\section{Distribution of lineament cross-points (CP)}

The values of the lineament CP were adjusted to exponential, lognormal and gamma laws (Table 3).

Table 3: Adjustment of lineaments' cross-points to statistical laws.

\begin{tabular}{cccc}
\hline $\begin{array}{c}\text { Cross-points } \\
\text { distribution laws }\end{array}$ & Chi2 calculated & $\begin{array}{c}\text { theoretical Chi2 }(\mathrm{a}= \\
10 \%)\end{array}$ & Degree of freedom \\
\hline $\begin{array}{c}\text { Exponential } \\
\text { Log-normal (86,6 \% }\end{array}$ & 138.31 & 13.36 & 8 \\
$\begin{array}{c}\text { of values) } \\
\text { Gamma }\end{array}$ & 248.21 & 12.02 & 7 \\
\hline
\end{tabular}

It appears from the fit test that the lineament CP are not described by any of the classical laws (calculated Chi2 > theoretical Chi2). However, the adjustment of the distribution of this lineament attribute to power law is acceptable, and the characteristic exponent $\alpha$ is equal to 4.59 (Figure $4 b$ ). This adjustment is valid for the nodes numbers superior to 7 per mesh.

The expression of the power law is:

$$
N(l)=64098 \times \ell^{-4,59}
$$

\section{Distribution of lineaments spacing}

Like the distribution of lineament CP, no laws (exponential, lognormal and gamma) allows to adjust the distribution of lineament spacing (Table 4). However, the power law fits spacing between 874.17 and $5006 \mathrm{~m}$ (Figure 4 c).

Table 4: Adjusting of lineaments' spacings to statistical laws.

\begin{tabular}{llll}
\hline $\begin{array}{l}\text { Spacings } \\
\text { distribution laws }\end{array}$ & $\begin{array}{c}\text { Chi2 } \\
\text { calculated }\end{array}$ & $\begin{array}{l}\text { theoretical Chi2 } \\
(\mathrm{a} \square=10 \%)\end{array}$ & Degree of freedom \\
\hline Exponential & 36.12 & 9.24 & 5 \\
Log-normal & 56.76 & 12.02 & 7 \\
Gamma & 17.62 & 6.25 & 3 \\
\hline
\end{tabular}


The expression of the power law in the case of spacing is below:

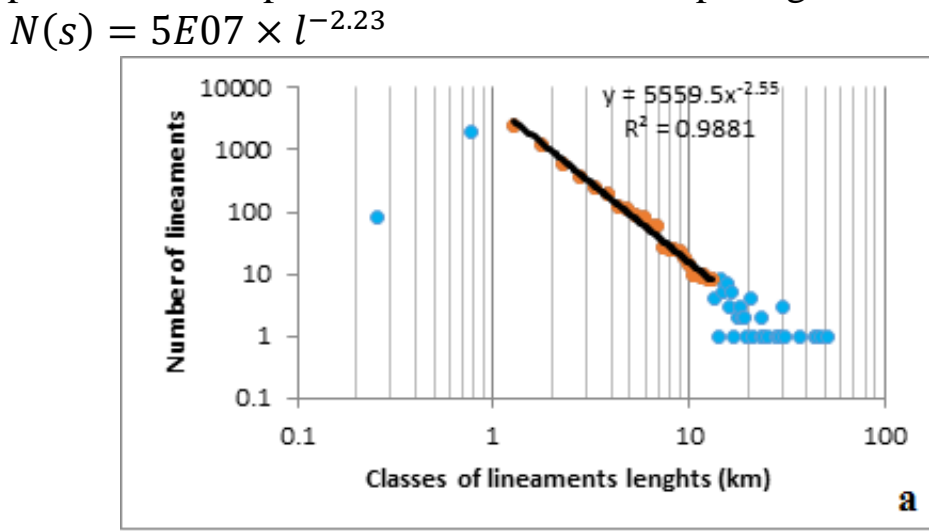

(4).
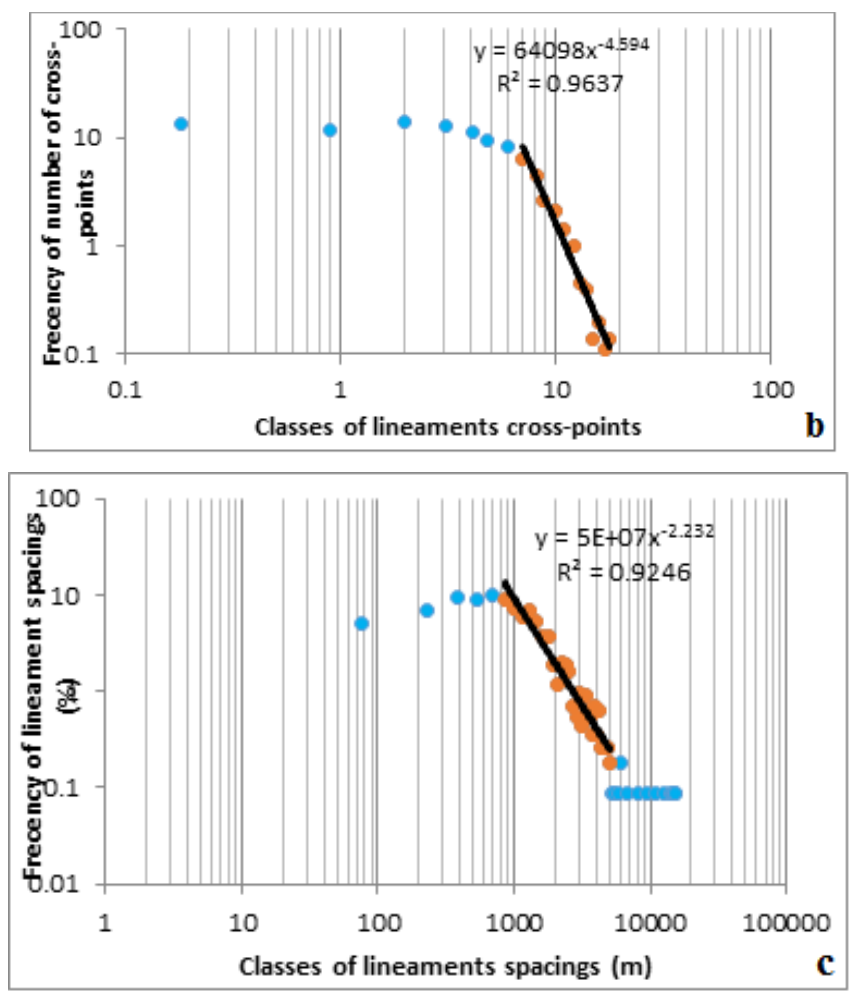

Figure 4: Adjustment of lineaments attributes to the power law: a) cumulative lengths, b) number of cross-points, c) spacings

\section{Geostatistical analysis of lineaments attributes}

\section{Lineament cumulative Lengths (CL)}

The experimental variogram of CL is structured (Figure5a and b), showing that the spatial deployment of lineaments is not random. This variogram is fitted to exponential model within overall observation approach 
(figure 5a). A practical range of $21.83 \mathrm{~km}$, a nugget effect (Co) of 5655.33 $\mathrm{km}^{2}$ and a plateaus $(\mathrm{C}+\mathrm{Co})$ equal to $25852.93 \mathrm{~km}^{2}$ are noted. However, within a detailed view, the experimental variogram shows a particular behavior, characterized by 3 levels, the last one seems uncompleted (Figure $5 b)$. The presence of different plateaus expresses the existence of several levels of correlation. This would highlight a nesting of some structures, at various scales. Taking into account the multi levels of experimental variogram, the global modeling equation in the case of adjusting to the exponential model is:

$$
\gamma(h)=5655.33+19344.67\left[1-\exp \left(\frac{-3 h}{29.5}\right)\right]+21844.67\left[1-\exp \left(\frac{-3 h}{46}\right)\right]
$$

This expression is the sum of the model equation of both the first and second level of the experimental variogram of CL. A nugget effect (Co) is obtained within the first level and is equal to $5655.33 \mathrm{~km}^{2}$. It represents $17.40 \%$ of the total variance. The $\mathrm{C}$ values, which are the difference between the sill and the nugget effect (Co) are equal to $19344.67 \mathrm{~km}^{2}$ and 21844.67 $\mathrm{km}^{2}$ for respectively the first and the second level of the experimental variogram. Also, the range values are respectively, $29.5 \mathrm{~km}$ and $46 \mathrm{~km}$ for the first and second level. The maximum range $(\mathrm{a} 2=46 \mathrm{~km})$ indicates a significant structuring of lineaments in the study area.
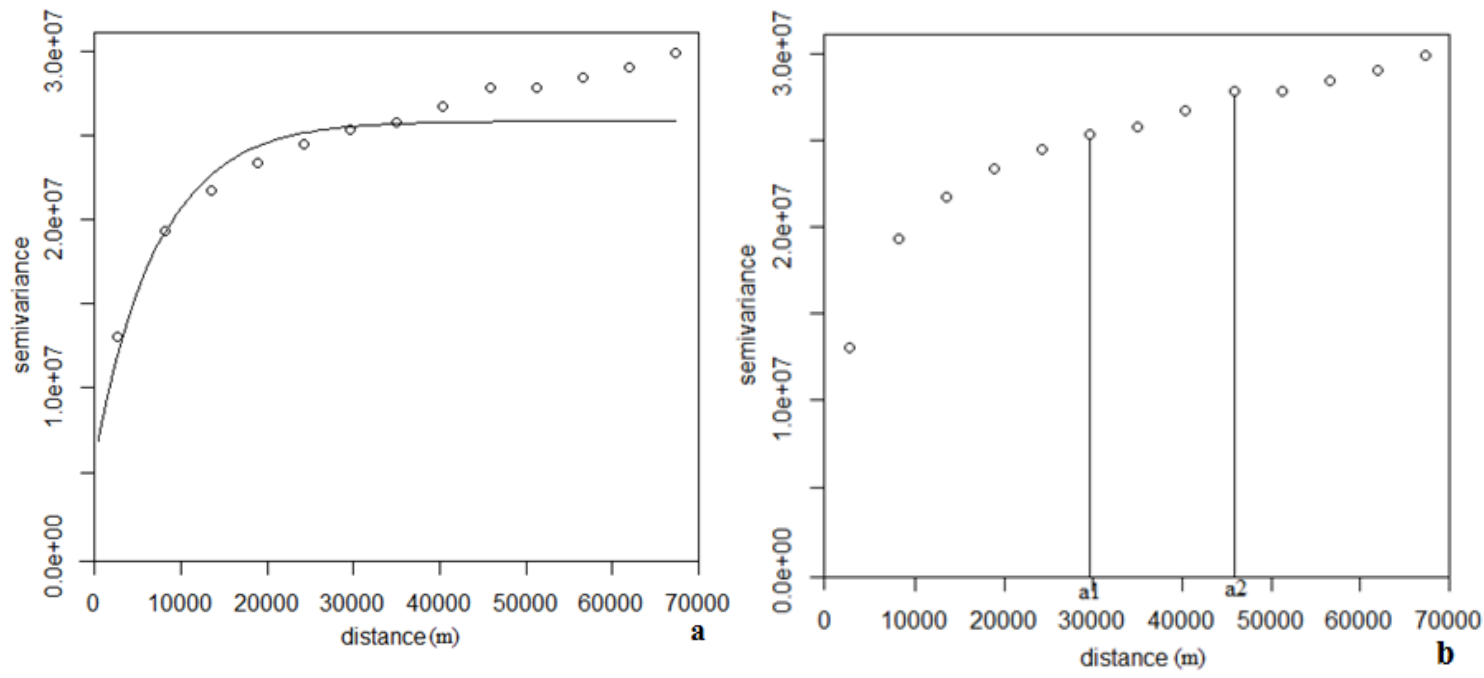

Figure 5: Variograms of cumulative length of lineaments:

a) analysis considering global observation,

b) analysis considering multi levels.

\section{Lineament cross-points (CP)}


The variogram of lineaments $\mathrm{CP}$ is illustrated in figure $6 \mathrm{a}$ and $\mathrm{b}$. It presents a spatial structuring, showing that lineament $\mathrm{CP}$ is a regionalized variable. The regionalization parameters, which are nugget effect, sill and range, obtains after fitting to exponential model (figure 6a), are 1.31, 7.84 and $9355.50 \mathrm{~m}$, respectively. Also, detail and subtle observation of this experimental variogram reveal the presence of two discrete levels inside (figure 6b). The global modeling equation, taking into account this two levels, is presented below, for the model exponential:

$$
\gamma(h)=1.31+6.29\left[1-\exp \left(\frac{-3 h}{11000}\right)\right]+6.59\left[1-\exp \left(\frac{-3 h}{20000}\right)\right]
$$

This relation is a summation of the modeling equation of the two levels of the experimental variogram. The nugget effect $(\mathrm{Co}=1.31)$ belongs to the first level of the variogram and represents $16.58 \%$ of the total variance. The variance $C$ values are 6.29 and 6.59 for respectively first and second level. Also, the correlation distances a1 et a2, are 11 et $20 \mathrm{~km}$, for the first level and second level, respectively.

The two variograms (CL and CP) exhibit the same behavior, within two discrete plateaus. Whatever, CL correlation range are quasi superior than CP's one.

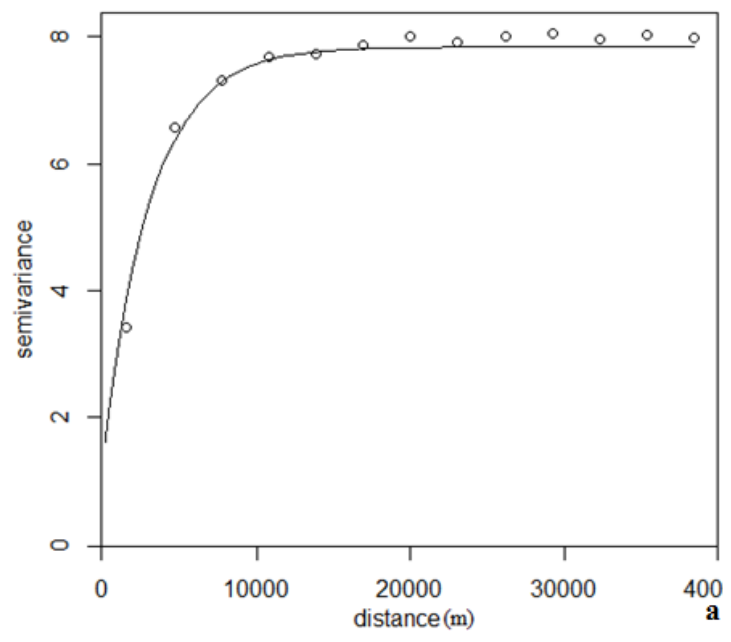

Figure 6: Variograms of cross-points of lineaments: a) analysis considering global observation,

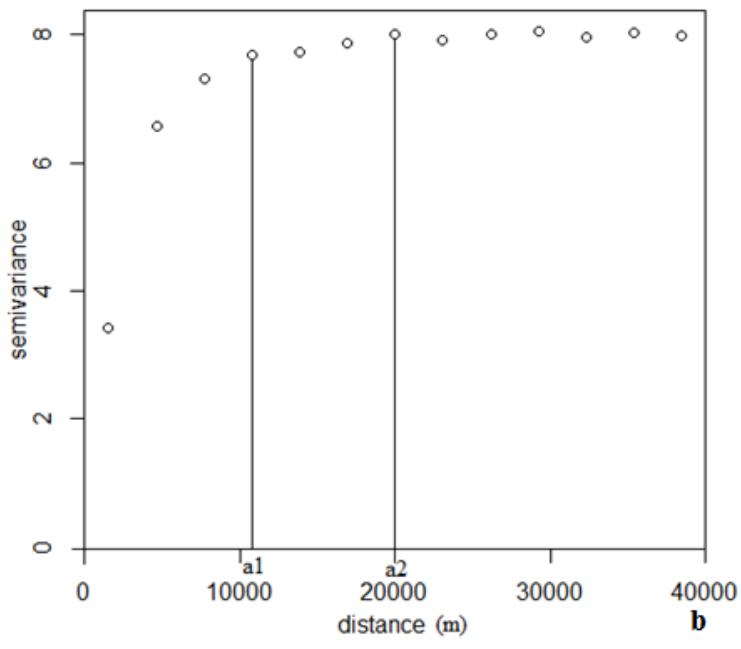

b) analysis considering multi levels

\section{Discussion}

\section{Statistical analysis}

The distribution of lineaments' length, cross-points and spacing, followed the power law and that could reflect the fractal nature of the fracture network of Divo-Oumé region. It conforms with the observation of Zazoun (2007), who noted that fractal analysis searches auto similarity. The aims of auto similarity is to show that the spatial distribution of fractures 
remains the same at different scales. This makes possible the translation of geometric properties from one scale to another.

The adjustment of lineaments lengths with the power law is consistent with the work of many authors (Bodin and Razack, 1999; Lasm 2000; Lasm and Razack, 2001; Kouamé et al, 2005, Jourda, 2005. Youan Ta, 2008, Baka, 2012; Lasm et al., 2014; Koudou et al., 2013, Koudou et al., 2014). These authors reported that the power law fits better in a crystalline rocks environment. The power law is valid for lineaments' lengths ranged from 1.28 to $13.04 \mathrm{~km}$. Lower values (lengths $<1.28 \mathrm{~km}$ ) are confronted to problem of "truncation" (Ackermann et al., 2001; Bonnet et al., 2001 and Zazoun., 2008) and beyond this range (length $>13.04 \mathrm{~km}$ ), the problem of "censoring" is observed. The effects of "truncation", due to short length fractures, sub-sampled due to limits of resolution detection and fractures sampling methods (Ackermann et al., 2001, Bonnet et al., 2001, Bodin and Razack 2001). The effects of "censoring" are caused by longer fractures which exceed the limits of the sampling window (Baka, 2012). The characteristic exponent $(\alpha=2.55)$ obtained is between 2 and 3 and is consistent with the literature data. It is an indicator of development stage of the fractures network (Lasm 2000; Darcel, 2002; Youan Ta et al., 2008). Bour and Davy (1997), Bonnet et al. (2001) and Darcel et al. (2003), reported that the connectivity of the fractured media is related to the exponent $\alpha$ and fractures density. Such connectivity may vary at the percolation threshold between 0 and 3.6. De Dreuzy et al. (2000) showed the influence of fracture lengths on 2D network connectivity and established a link with the exponent $\alpha$. In fact, these authors have observed that for $\alpha$ between 2 and 3, long and short length fractures control both connectivity, which is significantly dependent on the scale. The characteristic exponent obtained $(\alpha=2.55)$ in this study is consistent with the ones assessed by various authors who worked in the Precambrian basement of Côte d'Ivoire (Lasm 2000; Lasm and Razack, 2001; Kouamé et al., 2005; Youan Ta, 2008, Baka, 2012, Koudou et al., 2013, Koudou et al., 2014). In the Divo-Oumé area, fractures connectivity would be under the control of both long and short fractures which would thus, contributes to the groundwater flow.

The distribution of spacing follows the power law and this is consistent with the observations of Bodin and Razack (1999), Zazoun (2008), Baka (2012) and Koudou et al., (2013). The law of spacing distribution is still being discussed in the literature: gamma (Lasm 2000; Youan Ta, 2008; Youan Ta et al., 2008), exponential (Jourda, 2005; Koudou et al., 2014.), log-normal (Pascal et al., 1997; Odonne et al., 2007; Lemieux et al., 2009; DesRoches et al., 2014.), power and negative exponential (Lapointe and Hudson, 1985; Brooks et al., 1995), and power (Gillespie et al., 1993; Genter and Castaing, 1997). Several authors (Rives et al., 1992; 
Odling et al., 1999; Ackermann et al., 2001) used the coefficient of variation (CV) of spacings data to explain the spatial distribution of fractures network. Indeed, according to these authors, high values of CV (CV>100\%), indicate that the fractures network is composed of clustered (fractures clustered) and characterized by low distortion and low intensity of fracturing process. On the contrary, when fracturing process reaches a final stage, spacings are uniform and their distribution generally follow normal law and the coefficient of variation is low $(\mathrm{CV}<100 \%)$. In this study, the CV is low (CV $=51 \%$ ) and spacings distribution follows the power law. The CV value may notified that the region would be characterized by intense fracturing process. However, this theory has been contested by Gillespie (2003). For this author, the theory is not proven from a statistical point of view and in most cases, distributions following negative exponential or power laws, have low CV (CV <100\%).

\section{Geostatistical analysis}

The geostatistical analysis showed the structuring of lineaments CL and CP. This structuring, in particular for the CL, observed in Divo-Oumé region, is corroborated by the results of several authors (Lasm 2000; Jourda, 2005; Youan Ta, 2008; Youan Ta et al., 2008; Baka, 2012; De Lasme, 2013; Koudou et al. , 2013; Koudou et al., 2014) who worked in Precambrian basement media of Côte d'Ivoire. The dispersion (17.40\%) is lower than that obtained by Baka (2012) (24.18\%) in Oumé department. The nugget effect is commonly encountered in the geostatistical analysis of fractured media (Massoud, 1988; Lasm et al., 2004). Massoud (1988) reported that, within an experimental variogram, it is difficult to distinguish the microstructures effect from those of measurement errors. In Duekoue, western part of Côte d'Ivoire, Koudou et al., (2013), obtained variogram of fractures without nugget effect. These authors linked this singular result to the quality of ASTER images used for the structural mapping. Indeed, they noted that the best spatial and spectral resolution of ASTER images improved mapping of structural lineaments by significantly reducing measurement uncertainties. The multi-regionalization noted in Divo-Oumé area, was also observed by Baka (2012) in the region of Oumé, Lasm (2000), Lasm et al., (2004) in the Man area, Jourda (2005) in the region of Korhogo, Youan Ta (2008) and Youan Ta et al., (2008) in the region of Bondoukou. It could indicate the complexity of tectonic events in the Precambrian basement and the stage of development of fractures network. In Divo-Oumé, the multi-regionalization is perceived discreetly, contrary to western and northeastern area of Cote d'Ivoire, where it is well important and well-marked. Fractures network would relatively be better developed in Divo-Oumé, than in San-pédro area. Our conclusions are similar to those of Lasm et al., (2014), who noted that 
most developed fractures network are located in western and northeastern part of Côte d'Ivoire and the less develop ones are registered in the southern part.

The fact that the variograms of CL and CP have the same behavior, would highlight the intrinsic character of these two parameters. Indeed, the $\mathrm{CP}$ are set up at the crossing for two or more than two lineaments and in general, the more lineaments are long, the more they are conducive to the creating of CP. A significantly positive correlation would be established between the CL and CP of lineaments. The number of CP would therefore be important in areas with high CL values, and would be less important in spaces with low CL values. However, this correlation is not spatially omnipresent. The presence of lineaments in a given space, necessarily means the non-nullity of the random variable CL. This is not the case for the CP. There are spaces where the lineaments do not form CP. So, high CL values can coexist spatially with almost no CP values. These include, areas dominated by short length lineaments, the zone of massifs and spaces beyond the study area, where some lineaments extend. Therefore, the continuity of the function of the random variable CL has a larger range than those of the function of the random variable CP. Plausibly, it is why the CL correlation ranges are quasi higher than those of $\mathrm{CP}$.

\section{Conclusion}

The distribution of length of lineaments, their CP and spacings follow the power law and thus highlight the fractal nature of the fracture network. The value of the characteristic coefficient of the power law in the case of cumulative lengths $(\alpha=2.55)$ indicates the maturity of the network. The long and the short fractures contribute to connectivity within this fractures network. The geostatistical analysis showed that the variograms of cumulative lengths and cross-points exhibit the same behavior, highlighted by discrete multi levels of structuration. This reflects the intrinsic character of these two attributes of lineaments. However, the correlation ranges of CL are higher than those of CP.

These results could have important implications in the understanding of groundwater flow and the establishment of water resources management tools.

\section{References:}

1. Ackermann R.V., Schlische R.W. et Withjack M. (2001). The geometric and statistical evolution of normal fault systems: an experimental study of the effects of mechanical layer thickness on scaling laws. Journal of Structural Geology, 23, 1803-1819. 
2. Baka D. (2012). Géométrie, hydrodynamisme et modélisation des réservoirs fracturés du socle protérozoïque de la région d'Oumé (Centre-Ouest de la Cote d'Ivoire). Thèse Unique, Univ. F.H. Boigny, Abidjan, Côte d'Ivoire, 249 p.

3. Biémi J. (1992). Contribution à l'étude géologique, hydrogéologique et par télédétection des bassins versants sub-sahéliens du socle précambrien d'Afrique de l'Ouest : hydrostructurale, hydrodynamique, hydrochimie et isotopie des aquifères discontinus de sillons et aires granitiques de la haute Marahoué (Côte d'Ivoire). Thèse de Doctorat d'Etat ès Sciences Naturelles. Université de Cocody. Abidjan (Côte d'Ivoire). 493 p.

4. Bodin J. et Razack M. (1999). L'analyse d'images appliquée au traitement automatique de champs de fractures. Propriétés géométriques et lois d'échelles. Bulletin Société Géologique France, 170 (4) 579-593.

5. Bonnet E., Bour O., Odling N.E., Davy P., Main I.G., Cowie P.A. et Berkowitz B. (2001). Scaling of fracture systems in geological media. Review of Geophysics, 39, 347-383.

6. Bour O. et Davy P. (1997). Connectivity of random fault networks following a power law fault length distribution. Water Resources Research, 7, 1567-1583.

7. Brooks Clark M., Brantley S.L. et Fisher D.M. (1995). Power- law veinthickness distributions and positive feedback in vein growth. Geology. Geology, 23 (11), 975-978.

8. Cacas M.C., Ledoux E., Marsily G.D., Tillie B., Barbeau A., Durand E., Feuga B. et Peaudecerf P. (1990). Modelling fracture flow with a stochastic discrete fracture network: calibration and validation 1 . The flow model. Water Resources Research, 26 (3), 479-489.

9. CCT, Canada (2007). Notions fondamentales de télédétection. Cours tutoriel Centre Canadien de Télédétection. 266p

10. Chilès, J.P. (2004) La modélisation géostatistique de la variabilité spatial et ses applications.

11. Memoires des Sciences de la Terre $n^{\circ} 2004.01$, Ecole des Mines de Paris, France, 71

12. Chilès J.P., De Marsily G (1993). Stochastic models of fracture systems and their use in flow and transport modeling. In Flow and contamination transport in fractured rock. Edited by J. Bear, C.-F. Tsang, and G. de Marsily. Academic Press, London, 169-236.

13. Darcel C., Bour O., Davy P. et De Dreuzy J.R. (2003). Connectivity properties of two dimensional fracture networks with stochastic fractal correlation. Water Resources Research, 39, 1272-1285 
14. De Dreuzy J.R., Davy P. et Bour O. (2000). Percolation threshold of 3D random ellipses with xidely-scattered distributions of eccentricity and size. Physical Review E, 62, 5948-5952.

15. De Lasme, O. Z. 2013. Contribution à une meilleure connaissance des aquifères fissurés du socle précambrien ; cas de la région de San Pedro (Sud-ouest de la Côte d'Ivoire). Thèse Université Félix Houphouët-Boigny, 176 p.

16. Delhomme J.P. (1976). Application de la théorie des variables régionalisées dans les sciences de l'eau. Thèse de Docteur-Ingénieur, Ecole des Mines de Paris, Fontainebleau, Univ. Pierre et MarieCurie, 160 p.

17. Delor C., Diaby I., Simeon Y., Yao B., Djama A., Okou A., Konaté S., Taslet J-P., Vidal M., Traoré I., Dommanget A., Cautru J-P., Konan G. et Chiron J-C (1995). Carte Géologique de la Côte d’Ivoire à 1/200 000 ; Feuille Grand-Lahou, Mémoire de la Direction des Mines et de la Géologie, n5, Abidjan, Côte d’Ivoire.

18. DesRoches A., Danielescu S. et Butler K. (2014). Structural controls on groundwater flow in a fractured bedrock aquifer underlying an agricultural region of northwestern New Brunswick, Canada. Hydrogeology Journal. 22: 1067-1086.

19. Genter A. et Castaing C. (1997). Effets d'échelle dans la fracturation des granites. Compte Rendu Académie Sciences Paris, 325, 439-445.

20. Géomines (1982). Inventaire hydrogéologique appliqué à l'hydraulique villageoise. Ministère des Travaux Publics et des Transports, Direction Centrale de l'Hydraulique, République de Côte d’Ivoire, carte de Grand-Lahou. 26p.

21. Gillespie P.A. (2003). Comment on "The geometric and statistical evolution of normal fault systems: an experimental study of the effects of mechanical layer thickness on scaling laws” by R.V. Ackermann, R.W. Schlische and M.O. Withjack. Journal of Structural Geology, 25, 819-822

22. Gillespie P.A., Howard C.B., Walsh J.J. et Watterson J. (1993). Measurement and characterisation of spatial distributions of fractures. Tectonophysics, 226, 113-141.

23. Jourda J.P.R. (2005). Méthodologie d'application des techniques de télédétection et des systèmes d'information géographique à l'étude des aquifères fissurés d'Afrique de l'Ouest. Concept de l'hydrotechnique spatiale: cas des zones tests de la Côte d'Ivoire. Thèse de Doctorat d'Etat ès Sciences Naturelles. Univ. Cocody (Abidjan, Côte d'Ivoire). 403 p. 
24. Kim G-O., Lee J-Y., Lee K-K. (2004). Construction of lineament maps related to groundwater occurrence with ArcView and Avenue $^{\mathrm{TM}}$ scripts. Computer and Geosciences, 30, 1117-1126.

25. Kouadio Z. A, Goula T.A., Kouassi F. W., Kouakou K. E., Savané I. (2010) Apport des images satellitaires à l'étude de la dynamique de l'occupation du sol de bassins versants côtiers : exemple de l'Agnéby, de la Mé et du Boubo (Côte d'Ivoire). PhotoInterprétation European Journal of Applied Remote Sensing. 2, 5590.

26. Kouadio Z. A. (2011). Dynamique de l'occupation du sol et comportement hydrologique : cas des bassins versants côtiers de l'Agnéby et du Boubo (cote d'ivoire). Thèse Unique, Univ AboboAdjamé, Abidjan, Côte d'Ivoire.188p.

27. Kouamé K.F. (1999). Hydrogéologie des aquifères discontinus de la région semimontagneuse de Man-Danané (Ouest de la Côte d'Ivoire). Apport des données des images satellitales et des méthodes statistique et fractale à l'élaboration d'un système d'information hydrogéologique à référence spatiale. Thèse de Doctorat $3^{\text {ème }}$ cycle. Univ. Cocody. Abidjan (Côte d'Ivoire). 194 p.

28. Kouamé K.F., Akaffou A.G., Lasm T., de Dreuzy J.R., Davy P., Bour O., (2005). Simulation des écoulements dans les réservoirs fracturés application au socle Archéen de Touba (Nord-Ouest de la Côte d'Ivoire). Actes du Colloque International SITIS 05, Yaoundé (Cameroun), 27 Nov.-1er Déc. 2005, 39-46.

29. Koudou A., Lasm T., Kouame K.F., Youan Ta M., Assoma T. V., Biémi J. (2013) Contribution des images aster à la connaissance des aquifères fracturés de la région de Duékoué (Ouest de la Cote d'Ivoire). Photo-Interprétation, European Journal of Applied Remote Sensing, $\mathrm{n}^{\circ} 2012 / 4,48-66$.

30. Koudou A., Assoma T.V., Adiaffi B., Youan Ta M., Kouamé K. F., Lasm T., (2014) Analyses statistique et géostatistique de la fracturation extraite de l'imagerie ASAR ENVISAT du sud-est de la cote d'ivoire. Larhyss Journal, (20), 147-166.

31. Lachassagne P., Wyns R. and Dewandel B. (2011). The fracture permeability of Hard Rock Aquifers is due neither to tectonics, nor to unloading, but to weathering processes. Terra Nova, 23. 145-161

32. Lapointe P.R. et Hudson J.A. (1985). Characterization and Interpretation of Rock Mass Joint Patterns. Geological Society of America, Special Publication 199, 37 p.

33. Lasm T. (2000). Hydrogéologie des réservoirs fracturés de socle : analyses statistique et géostatistique de la fracturation et des propriétés hydrauliques. Thèse unique. Univ. Poitiers (France). 233p. 
34. Lasm T. et Razack M. (2001). Lois d'échelle dans la fracturation des roches dures cristallines et dans le réseau hydrographique associé. Compte Rendu Académie Sciences Paris, 333, 225-232.

35. Lasm T., Kouamé K.F., Soro N., Jourda J.P.R. et Biémi J. (2004). Analyse géostatistique de la fracturation extraite de l'imagerie spatiale aeroportée et satellitaire. Application à la région de ManDanané (Ouest de la Côte d'Ivoire). Revue Ivoirienne des Sciences et Technologiques, 5, 135-154.

36. Lemieux J-M, Kirkwood D, Therrien R (2009). Fracture network analysis of the St-Eustache quarry, Quebec, Canada, for groundwater resources management. Can Geotech J 46(7), 828-841.

37. Long J.C.L and Billeaux D.M. (1987). From field data to fracture network modeling: an example incorporating spatial structure. Water Ressources Research 23(7), 1201-1216.

38. Massoud H. (1988). Modélisation de la petite fracturation par les techniques de la géostatistique. Bulletin B.R.G.M., 155, 197pp.

39. Odling N.E., Gillespie P.A., Bourgine B., Castaing C., Chiles J.P., Christensen N.P., Fillion E., Genter A., Olsen C., Thrane L., Trice R., Aarseth E., Walsh J.J. et Watterson J. (1999). Variations in fracture system geometry and their implications for fluid flow in fractured hydrocarbon reservoirs. Petroleum Geoscience, 5 (4), 373-384.

40. Odonne F., Lezin C., Massonnat G. et Escadeillas G. (2007). The relationship between joint aperture, spacing distribution, vertical dimension and carbonate stratification: An example from the Kimmeridgian limestones of Pointe-du-Chay (France). Journal of Structural Geology, 29, 746-758.

41. Pascal C., Angelier J., Cacas M.C. et Hancock P.L. (1997). Distribution of joints: probabilistic modeling and case study near Cardiff (Wales, U.K.). Journal of Structural Geology, 19 (10), 12731284.

42. Razack M. (1984). Application des méthodes numériques et statistiques à l'identification des réservoirs fissurés carbonatés en hydrogéologie. Thèse de Doctorat ès Sciences. Université Languedoc (France). $394 \mathrm{p}$

43. Rives T., Razack M., Petit J.P. et Rawnsley K.D. (1992). Joint spacing: analogue and numerical simulations. Journal of Structural Geology, 14, (8-9), 925-937.

44. Savané I. (1997). Contribution à l'étude géologique et hydrogéologique des aquifères discontinus du socle cristallin d'Odienné (Nord-Ouest de la Côte d'Ivoire). Apport de la télédétection et d'un système d'information géographique à référence 
spatiale. Thèse de Doctorat d'Etat ès Sciences Naturelles. Univ. Cocody (Côte d'Ivoire). 332 p.

45. Savané I., Goze B. et Biémi J. (1995). Evaluation des ressources en eau dans le socle par l'étude des fractures à l'aide des données Landsat (Bassin d’Odienné, Côte d’Ivoire). Télédétection et Gestion des ressources en Eau, Colloque FAO, Montpellier, 29 Nov. au 01 Dec. 1995.

46. Soro N. (2002). Hydrochimie et géochimie isotopique des eaux souterraines du degré carré de Grand-Lahou et ses environs (SudOuest de la Côte d'Ivoire). Implication hydrologique et hydrogéologique. Thèse de doctorat d’Etat, Université de Cocody, Côte d'Ivoire, 272 pp.

47. Tagini B. (1971). Esquisse structurale de la Côte d'Ivoire. Essai de géotechnique régionale.

48. Thèse d'État. Université de Lausanne (Suisse). 302 p.

49. Wyns R., Baltassat J.M., Lachassagne P., Legtchenko A. and Vairon J. (2004). Application of proton magnetic resonance soundings to groundwater reserves mapping in weathered basement rocks (Brittany, France). Bull. Soc. Géol. Fr., 175. 2134.

50. Youan Ta M., Lasm T., Jourda J.P.R., Kouamé K.F. et Razack M. (2008). Cartographie des accidents géologiques par imagerie satellitaire Landsat-7 ETM+ et analyse des réseaux de fractures du socle précambrien de la région de Bondoukou (Nord-Est de la Côte d'Ivoire).

51. Télédétection, Vol. 8, N², pp. 119-135

52. Youan Ta M. (2008). Contribution de la télédétection et des systèmes d'informations géographiques à la prospection hydrogéologique du socle précambrien d'Afrique de l'ouest : cas de la région de Bondoukou (Nord-Est de la Côte d'Ivoire). Thèse Unique. Université de Cocody. Abidjan (Côte d'Ivoire). 237 p

53. Zazoun R. (2007). La région du Fadnoun, Tassili n'Ajjer, Algérie: géométrie d'un réseau de fracturation à caractère fractal? Communication au Sixième Séminaire de Géologie Pétrolière, Hôtel Hilton, Alger., Hotel Hilton, du 15 au 16 Avril 2007. SonatrachCentre de Recherche et Développement.

54. Zazoun R.S. (2008). The Fadnoun area, Tassili-n-Azdjer, Algeria: Fracture network geometry analysis. Journal of African Earth Sciences, Vol. 50, N5, pp. 273-285. 